\title{
Inhibitory Spectrum of Talopeptin (MKI), a Specific Inhibitor of Thermolysin
}

\author{
Keiko Kitagishi and Keitaro HIROMI \\ Department of Food Science and Technology, Faculty of Agriculture, \\ Kyoto University, Sakyo-ku, Kyoto 606, Japan \\ Received November 16, 1983
}

\begin{abstract}
Talopeptin ( $N$-(6-deoxy- $\alpha$-L-talopyranosyloxyphospho)-L-leucyl-L-tryptophan), a specific inhibitor for thermolysin and some other endo-type metalloproteases, does not inhibit superoxide dismutase, alkaline phosphatase, or carbonic anhydrase, which are $\mathrm{Zn}$ (II)-enzymes, in the inhibitor concentration of the order of $10^{-4} \mathrm{M}$. Although the enzyme activity of carboxypeptidase A, a $\mathrm{Zn}$ (II)-containing exo-type metalloprotease, is slightly reduced by the addition of talopeptin, the inhibition is not significant at the $10 \%$ level judged by Student's $t$ test. On the other hand, talopeptin seemed to act as an inhibitor for all dehydrogenases examined, most of which do not contain $\mathrm{Zn}$ (II), at the inhibitor concentration studied (around $10^{-4} \mathrm{M}$ ). It is possible that the phosphite group of talopeptin binds to the same site on the dehydrogenase as the one for the phosphate group of the coenzyme.
\end{abstract}

Talopeptin (MKI) specifically inhibits metalloproteases, including thermolysin. ${ }^{1)}$. The Xray crystallographic study of the threedimensional structure of the complex between thermolysin and phosphoramidon $(N-(\alpha-\mathrm{L}-$ rhamnopyranosyloxyphospho)-L-leucyl-Ltryptophan) has suggested that the phosphite oxygen of phosphoramidon and talopeptin binds to the zinc ion in the catalytic site of the enzyme. $^{2)}$

The question naturally arises whether or not talopeptin can bind and inhibit other metalloenzymes, especially those containing $\mathrm{Zn}$ (II). In this paper, was investigated the inhibitory activity of talopeptin against $\mathrm{Zn}$ (II)-containing enzymes (carboxypeptidase A, carbonic anhydrase, alkaline phosphatase, superoxide dismutase, and alcohol dehydrogenase $)^{3)}$ and also against other dehydrogenases that do not contain $\mathrm{Zn}(\mathrm{II})$.

\section{MATERIALS AND METHODS}

(a) Materials.

Enzymes. Commercial products from Boehringer Mannheim $\mathrm{GmbH}$ : alcohol dehydrogenase (ADH) (EC 1.1.1.1) from yeast and $\mathrm{ADH}$ from horse liver, lactate dehydrogenase (LDH) (EC 1.1.1.27) from rabbit muscle, carbonic anhydrase (CA) (EC 4.2.1.1) from beef erythrocytes, and carboxypeptidase A (CPA) (EC 3.4.17.1) from beef pancreas. From the Oriental Yeast Co., Ltd.: $\alpha$ glycerophosphate dehydrogenase $(\alpha-\mathrm{GDH})(\mathrm{EC}$ 1.1.1.8) from rabbit muscle, LDH from Leuconostoc mesenteroides, malate dehydrogenase (MDH) (EC 1.1.1.37) from yeast, MDH from pig heart, glucose-6-phosphate dehydrogenase (G6PDH) (EC 1.1.1.49) from yeast (Grade I and II), and glutamate dehydrogenase (GLDH) (EC 1.4.1.3) from beef liver. From the Sigma Chemical Co.: $\mathrm{MDH}$ from beef heart and alkaline phosphatase (AP) (EC 3.1.3.1) from E. coli. From Miles Laboratories Limited: superoxide dismutase (SOD) (EC 1.15.1.1) from beef erythrocytes. From P.-L. Biochemicals, Inc. : xanthine oxidase (EC 1.2.3.2) from buttermilk.

Coenzymes, substrates. NAD, NADH, and NADP were purchased from P.-L. Biochemicals, Inc. Dihydroxy-

Abbreviations: talopeptin (MKI), $N$-(6-deoxy- $\alpha$-L-talopyranosyloxyphospho)-L-leucyl-L-tryptophan; DH, dehydrogenase; ADH, alcohol dehydrogenase (EC 1.1.1.1); $\alpha-\mathrm{GDH}, \alpha$-glycerophosphate dehydrogenase (glycerol-3phosphate dehydrogenase) (EC 1.1.1.8); LDH, lactate dehydrogenase (EC 1.1.1.27); $\mathrm{MDH}$, malate dehydrogenase (EC 1.1.1.37); G6PDH, glucose-6-phosphate dehydrogenase (EC 1.1.1.49); GLDH, glutamate dehydrogenase (EC 1.4.1.3); AP, alkaline phosphatase (EC 3.1.3.1); CA, carbonic anhydrase (EC 4.2.1.1); SOD, superoxide dismutase (EC 1.15.1.1); CPA, carboxypeptidase A (EC 3.4.17.1); DL-HPLA, hippuryl-DL-phenyllactic acid; DAP, dihydroxyacetone phosphate. 
Table I. The Composition of the Reaction Mixtures FOR THE DEHYDROGENASE ASSAYS

\begin{tabular}{|c|c|c|c|c|}
\hline DH & Source & {$[\mathrm{E}]_{0}$} & {$[\text { Coenzyme }]_{0}$} & {$[\mathrm{~S}]_{0}$, etc. } \\
\hline \multirow[t]{2}{*}{ ADH } & Yeast & $1 \mathrm{~nm}$ & $1.5 \mathrm{~mm}[\mathrm{NAD}]$ & $0.015 \sim 0.12 \mathrm{M}$ [ethanol] \\
\hline & Horse liver & $0.22 \mu \mathrm{g} / \mathrm{ml}$ & $2.0 \mathrm{~mm}[\mathrm{NAD}]$ & $67 \mathrm{~mm}$ [ethanol] \\
\hline$\alpha$-GDH & Rabbit muscle & $0.039 \mathrm{U} / \mathrm{ml}$ & $0.14 \mathrm{~mm}[\mathrm{NADH}]$ & $0.19 \mathrm{~mm}[\mathrm{DAP}]$ \\
\hline \multirow{2}{*}{ LDH } & Rabbit muscle & $32 \mathrm{ng} / \mathrm{ml}$ & $0.18 \mathrm{~mm}[\mathrm{NADH}]$ & $2.8 \mathrm{~mm}$ [pyruvate] \\
\hline & $\begin{array}{l}\text { Leuconostoc } \\
\quad \text { mesenteroides }\end{array}$ & $0.033 \mathrm{U} / \mathrm{ml}$ & $0.17 \mathrm{~mm}[\mathrm{NADH}]$ & $2.8 \mathrm{~mm}$ [pyruvate] \\
\hline \multirow[t]{3}{*}{$\mathrm{MDH}$} & Yeast : & $0.10 \mathrm{U} / \mathrm{ml}$ & $0.13 \mathrm{~mm}[\mathrm{NADH}]$ & $1.7 \mathrm{~mm}$ [oxalic acetate] \\
\hline & Pig heart & $0.18 \mathrm{U} / \mathrm{ml}$ & $0.09 \mathrm{~mm}[\mathrm{NADH}]$ & $1.3 \mathrm{~mm}$ [oxalic acetate] \\
\hline & Beef heart & $0.25 \mathrm{U} / \mathrm{ml}$ & $0.16 \mathrm{~mm}[\mathrm{NADH}]$ & $1.3 \mathrm{~mm}$ [oxalic acetate] \\
\hline \multirow[t]{2}{*}{ G6PDH } & Yeast (Grade I) & $0.028 \mathrm{U} / \mathrm{ml}$ & $0.50 \mathrm{~mm}[\mathrm{NADP}]$ & $0.50 \mathrm{~mm}[\mathrm{G} 6 \mathrm{P}], 20 \mathrm{mM}\left[\mathrm{MgCl}_{2}\right]$ \\
\hline & (Grade II) & $0.028 \mathrm{U} / \mathrm{ml}$ & $0.50 \mathrm{~mm}$ [NADP] & $0.50 \mathrm{~mm}[\mathrm{G} 6 \mathrm{P}], 20 \mathrm{~mm}\left[\mathrm{MgCl}_{2}\right]$ \\
\hline GLDH & Beef liver & $4.8 \mathrm{~nm}$ & $0.16 \mathrm{~mm}[\mathrm{NADH}]$ & $\begin{array}{l}3.3 \mathrm{mM}\left[2-\mathrm{ketog}^{2} \text { lutarate], }\right. \\
0.13 \mathrm{mM}\left[\mathrm{NH}_{4} \mathrm{Cl}\right], 83 \mu \mathrm{M} \text { [EDTA] }\end{array}$ \\
\hline
\end{tabular}

acetone phosphate (DAP) was obtained by hydrolyzing dihydroxyacetone phosphate dimethylketal (Boehringer Mannheim $\mathrm{GmbH}$ ).

(b) Methods. Rates of the enzyme reactions were determined as follows: The initial rate was obtained from the course recorded by spctrophotometer or pH-stat, except for carbonic anhydrase (see below). Enzyme concentrations employed, except for superoxide dismutase, were confirmed to be within the range where the initial rate was proportional to the enzyme concentration.

Dehydrogenases. The rate of the enzymatic reaction was measured at $340 \mathrm{~nm}$ through the rate of formation or disappearance of NADH or NADPH at $25^{\circ} \mathrm{C}$ with a spectrophotometer Union-Giken SM-401. The composition of the reaction mixtures $(1.5 \mathrm{ml}, \mathrm{pH} 7.5$ Tris buffer) for the various enzymatic assays is listed in Table I (optical path: $1 \mathrm{~cm}$ ).

Alkaline phosphatase. Enzymatic activity was estimated essentially according to the method of Neil and Horner, ${ }^{4)}$ measuring the increase in absorbance at $420 \mathrm{~nm}$ after the addition of the enzyme with a Shimadzu UV-200 spectrophotometer at $25^{\circ} \mathrm{C}$. The reaction mixture contains $p$ nitrophenyl phosphate and $2 \mu \mathrm{g}$ of the enzyme in $3 \mathrm{ml}$ Tris buffer $\mathrm{pH} 8.0$, and the concentration of $p$-nitrophenyl phosphate employed is $25 \mu \mathrm{M}$ or $1 \mathrm{~mm}$.

Carbonic anhydrase. Carbon dioxide solutions were prepared by bubbling $\mathrm{CO}_{2}$ from a gas cylinder (Gasukuro Kogyo Co., Ltd.) into $\mathrm{H}_{2} \mathrm{O}$. The concentration of $\mathrm{CO}_{2}$ in solutions was determined by the addition of an aliquot to a measured excess of $0.04 \mathrm{M} \mathrm{Ba}(\mathrm{OH})_{2}$ and back titration with $0.01 \mathrm{~N} \mathrm{HCl}$, with phenolphthalein as the indicator. ${ }^{5)}$ The course of the reaction was followed spectrophotometrically (at $400 \mathrm{~nm}$ ) through the rate of $\mathrm{pH}$ change by using $p$-nitrophenol as the indicator, after mixing the $\mathrm{CO}_{2}$ solution, $p$-nitrophenol, and the enzyme, with a UnionGiken SM-401 spectrophotometer. The enzyme reaction was carried out with $4.3 \mathrm{~mm} \mathrm{CO}_{2}, 91 \mu \mathrm{M}$ p-nitrophenol,
$4.1 \mathrm{ng} / \mathrm{ml}$ enzyme, and $\mathrm{pH} 6.4,10 \mathrm{~mm}$ PIPES buffer at $14^{\circ} \mathrm{C}$ (total volume: $1.5 \mathrm{ml}$ ). The reaction obeyed firstorder kinetics, and the apparent first-order rate constant was estimated from the course, which was used as the measure of the enzyme reaction rate.

Superoxide dismutase. Because of the instability of its substrate, the superoxide radical, an indirect assay had to be carried out for this enzyme. The inhibition of the rate of reduction of ferricytochrome $c$ by superoxide anion formed in the aerobic xanthine oxidase-xanthine system was measured spectrophotometrically at $550 \mathrm{~nm}$ and $25^{\circ} \mathrm{C}^{6 \text { ) }}$ The reaction mixture $(2 \mathrm{ml}$, Tris buffer) contained cytochrome $c$, xanthine, and EDTA, whose concentrations were $10 \mu \mathrm{M}, 50 \mu \mathrm{M}$, and $0.1 \mathrm{~mm}$, respectively, and xanthine oxidase was added to produce a rate of reduction of cytochrome $c$ of 0.023 absorbance change per min at $550 \mathrm{~nm}\left([\mathrm{E}]_{0} \simeq 5 \times 10^{-9} \mathrm{M}\right)$, in the absence of superoxide dismutase. The addition of $1.38 \mathrm{U}$ superoxide dismutase to the reaction mixture reduced the rate of the xanthine oxidase-catalyzing reaction to $53 \%$.

Carboxypeptidase $A$. Esterase activity of carboxypeptidase A (CPA) was measured by using hippuryl-DLphenyllactic acid (DL-HPLA) as a substrate with a $\mathrm{pH}$ stat apparatus (RTS 822 titration recording system, Radiometer, Copenhagen). The enzyme reaction was carried out in a thermostatted cell at $25^{\circ} \mathrm{C}$ under an $\mathrm{N}_{2}$ gas stream with $10 \mathrm{~mm}$ HPLA, $16 \mathrm{~nm}$ enzyme, and $5 \mathrm{~mm}$ Tris buffer $(50 \mathrm{~mm} \mathrm{NaCl}) \mathrm{pH} 7.5$, in a volume of $3.0 \mathrm{ml}$.

\section{RESULTS AND DISCUSSION}

The results obtained are summarized in Table II. Student's $t$ test was used to judge whether or not talopeptin inhibits the enzyme under the conditions employed. The number of stars indicates the confidence limit. 
Table II. Inhibition Spectrum of TAlopeptin against Zn(II)-Containing ENZYMES AND DEHYDROGENASES

\begin{tabular}{|c|c|c|c|c|c|c|}
\hline Enzyme & Source & $\begin{array}{c}\text { Essential } \\
\mathrm{Zn}(\mathrm{II}) \\
\text { involvement }\end{array}$ & $\begin{array}{c}{[\mathrm{I}]} \\
(\mathrm{mM})\end{array}$ & $\begin{array}{l}\text { Residual } \\
\text { activity } \\
(\%)^{a}\end{array}$ & $\begin{array}{l}\text { Rough esti- } \\
\text { mation of } \\
K_{i}(\mathrm{mM})^{b}\end{array}$ & $\begin{array}{l}\text { Reaction } \\
\text { conditions }\end{array}$ \\
\hline $\mathrm{AP}$ & E. coli & 0 & 0.46 & 99 & & $\mathrm{pH} 8.0,25^{\circ} \mathrm{C}$ \\
\hline $\mathrm{CA}$ & Beef erythrocytes & $\bigcirc$ & 0.86 & 105 & & $\mathrm{pH} 6.4,14^{\circ} \mathrm{C}$ \\
\hline SOD & Beef erythrocytes & 0 & 0.88 & 98 & & $\mathrm{pH} 8.0,25^{\circ} \mathrm{C}$ \\
\hline CPA & Beef pancreas & 0 & 0.70 & 86 & & $\mathrm{pH} 7.5,25^{\circ} \mathrm{C}$ \\
\hline \multicolumn{7}{|c|}{ Dehydrogenase } \\
\hline \multirow[t]{2}{*}{$\mathrm{ADH}$} & Yeast & O & $0.2 \sim 0.4$ & & $0.4^{c}$ & \\
\hline & Horse liver & 0 & 0.66 & $92 * * *$ & 8 & \\
\hline$\alpha-\mathrm{GDH}$ & Rabbit muscle & $x$ & 0.35 & $31 * * *$ & 0.2 & \\
\hline \multirow[t]{2}{*}{ LDH } & Rabbit muscle & $x$ & 0.86 & $62 * * *$ & 1.4 & \\
\hline & $\begin{array}{l}\text { Leuconostoc } \\
\quad \text { mesenteroides }\end{array}$ & $\times(?)$ & 0.86 & $91 * *$ & 9 & $\mathrm{pH} 7.5,25^{\circ} \mathrm{C}$ \\
\hline \multirow[t]{3}{*}{$\mathrm{MDH}$} & Yeast & $x$ & 0.66 & $82 * *$ & 3 & \\
\hline & Pig heart & $x$ & 0.66 & $58 * * *$ & 0.9 & \\
\hline & Beef heart & $x$ & 0.35 & $60 * * *$ & 0.5 & \\
\hline \multirow[t]{2}{*}{ G6PDH } & Yeast (Grade I) & $x$ & 0.66 & $72 * * *$ & 2 & \\
\hline & (Grade II) & $\times$ & 0.66 & $88 * * *$ & 5 & \\
\hline GLDH & Beef liver & $x^{\prime}$ & 0.37 & $71^{* * *}$ & 0.9 & \\
\hline
\end{tabular}

a Student's $t$ test was carried out to estimate the significance of the inhibition by talopeptin. The number of stars indicates the confidence limit. ${ }^{*}$ Significant at $10 \%$ level. $* *$ Significant at $5 \%$ level. $* * *$ Significant at $1 \%$ level.

$b$ The values are accompanied with a $\pm 50 \%$ error, at maximum.

$c \quad$ This value was estimated from an $s / v$ vs. $s$ (Hofstee plot).

Carboxypeptidase A, alkaline phosphatase, carbonic anhydrase, and superoxide dismutase

All of these four enzymes contain $\mathrm{Zn}(\mathrm{II})$. For carboxypeptidase A and carbonic anhydrase, the possibility is suggested that $\mathrm{Zn}$ (II) of the enzymes could act as a Lewis acid, withdrawing electrons from certain atomic groups of the substrate molecule, ${ }^{3,7)}$ as in the case of thermolysin. ${ }^{8)}$ Superoxide dismutase catalyzes an apparently diffusion-controlled oxidation of the superoxide radical at the $\mathrm{Cu}$ (II) ion of the enzyme catalytic center. ${ }^{9)}$ The function of the second metal, $\mathrm{Zn}(\mathrm{II})$, present in each subunit is not clear. It appears likely that $\mathrm{Zn}(\mathrm{II})$ is essential for stabilizing this enzyme. ${ }^{10}$ ) Alkaline phosphatase from E. coli (MW $80,000)$ contains four atoms of tightly bound $\mathrm{Zn}$ (II) and two $\mathrm{Mg}(\mathrm{II})$ per mol. ${ }^{11,12)}$ Two zinc atoms of the four are essential to catalytic activity $^{13)}$ and the additional two stabilize the protein structure. ${ }^{14)}$

Talopeptin does not inhibit superoxide dis- mutase, alkaline phosphatase, or carbonic anhydrase at all in the inhibitor concentration range employed (around $10^{-4} \mathrm{M}$ ). The inhibition of carboxypeptidase A (Table II) cannot be deemed significant at the $10 \%$ level judged by Student's $t$ test. It is noticeable that the interaction with talopeptin is entirely different for the two metalloproteases, carboxypeptidase $\mathrm{A}$ and thermolysin. One possible interpretation is that the dipeptide part of the inhibitor is too large to fit the substrate binding pocket $\left(S_{1}{ }^{\prime}\right)$ of the exopeptidase, carboxypeptidase A. ${ }^{15)}$ In fact, Kam et al. reported that $N$-phosphorylphenylalanine is a good inhibitor of carboxypeptidase A $\left(K_{i}=5 \times\right.$ $10^{-6} \mathrm{M}$ ), but a larger inhibitor, $N$-phosphorylleucyltryptophan, shows appreciably weaker inhibition $\left(K_{i}=5.4 \times 10^{-5} \mathrm{M}\right) .{ }^{16)}$

\section{Dehydrogenases}

Talopeptin inhibits all dehydrogenases examined in the inhibitor concentration range 
around $10^{-4} \mathrm{M}$, as seen from Table II.

Horse liver alcohol dehydrogenase ( a dimeric protein) contains two $\mathrm{Zn}(\mathrm{II})$ ions per monomer. One zinc ion at the bottom of the active site cleft is essential for the enzyme activity, while another lies in the periphery of the subunit and may be important in maintaining the protein structure. ${ }^{17)}$ The involvement of $\mathrm{Zn}$ (II) as a Lewis acid catalyst in liver alcohol dehydrogenase has been suggested. ${ }^{18)}$ Some investigations provide the evidence for zinc-bond water as the ionizing functional group involved in coenzyme binding, proton release, and conformational stability in the liver alcohol dehydrogenase reaction. ${ }^{19 \sim 22)}$ Alcohol dehydrogenases from other sources also contain catalytically essential $\mathrm{Zn}(\mathrm{II}){ }^{18)}$ Some other dehydrogenases were originally thought to be zinc metalloproteins. ${ }^{23 \sim 26)}$ However, further studies demonstrated that the zinc ion in bovine glutamate dehydrogenase is not an essential constituent of the enzyme but may function as an allosteric effector, ${ }^{27)}$ and that no significant amounts of zinc or other metals are contained in lactate dehydrogenases and malate dehydrogenases, ${ }^{28 \sim 30)}$ despite the structural similarities among dehydrogenases. ${ }^{31}$ )

The inhibition for some of lactate dehydrogenases and malate dehydrogenases, which have been regarded as non-zinc enzymes, are stronger than that for horse liver alcohol dehydrogenase, a zinc-containing enzyme. Accordingly, it can be concluded that talopeptin is able to bind also to dehydrogenases which do not contain $\mathrm{Zn}(\mathrm{II})$, and it does not necessarily bind to the $\mathrm{Zn}$ (II) of alcohol dehydrogenase. In fact, Colman and Foster found that 1,10-phenanthroline, a $\mathrm{Zn}$ (II)-chelating compound, inhibits zinc-free glutamate dehydrogenase. $^{27)}$

Probably the talopeptin binding site is not far from the active sites of the dehydrogenases. One possibility is that talopeptin binds near the coenzyme (NAD or NADP) binding site, and the phosphite group of talopeptin binds to the binding site for the phosphate group of the coenzyme. This interpretation is not unreason- able, since both talopeptin and coenzyme have sugar(s) (6-deoxytalose and riboses, respectively) in addition to the similarity in the phosphite or phosphate group. Most dehydrogenases have the Michaelis constants, $K_{m}$ 's, for coenzymes in the range of $10^{-5} \sim 10^{-3} \mathrm{M}^{32)}$ The inhibitor constants of talopeptin, $K_{i}$ 's, for dehydrogenases are roughly $10^{3} \sim 10^{5}$ times as large as its $K_{i}$ for thermolysin $\left(4 \times 10^{-8} \mathrm{M}\right.$ at $\mathrm{pH} 7.5$ and $\left.\left.25^{\circ} \mathrm{C}\right),{ }^{33}\right)$ but slightly larger than the $K_{m}$ 's of the coenzymes for dehydrogenases.

Acknowledgment. We wish to thank to Dr. Sawao Murao, Professor of University of Osaka Prefecture, and Dr. Kohei Oda (University of Osaka Prefecture) for their generous gifts of pre-crystalline preparations of talopeptin.

\section{REFERENCES}

1) S. Murao, M. Katsura, K. Fukuhara and K. Oda, Agric. Biol. Chem., 44, 701 (1980).

2) L. H. Weaver, W. R. Kester and B. W. Matthews, J. Mol. Biol., 114, 119 (1977).

3) J. F. Chlebowski and J. E. Coleman, "Metal Ions in Biological Systems," Vol. VI, ed. by H. Sigel, Marcel Dekker, Inc., New York, 1976, pp. 1 140.

4) M. W. Neil and M. W. Horner, Biochem. J., 92, 217 (1964).

5) B. H. Gibbons and J. T. Edsall, J. Biol. Chem., 238, 3502 (1963).

6) B. B. Keele, Jr., J. M. McCord and I. Fridovich, J. Biol. Chem., 246, 2875 (1971).

7) W. N. Lipscomb, Tetrahedron., 30, 1725 (1974).

8) M. K. Pangburn and K. A. Walsh, Biochemistry, 14, 4050 (1975).

9) G. Rotilio, L. Morpurgo, C. Giovagnoli, L. Calabrese and B. Mondovi, Biochemistry, 11, 2187 (1972).

10) H. J. Forman and I. Fridovich, J. Biol. Chem., 248, 2645 (1973).

11) W. F. Bosron, F. S. Kennedy and B. L. Vallee, Biochemistry, 14, 2275 (1975).

12) W. F. Bosron, R. A. Anderson, M. C. Falk, F. S. Kennedy and B. L. Vallee, Biochemistry, 16, 610 (1977).

13) D. J. Plocke, C. Levinthal and B. L. Vallee, Biochemistry, 1, 373 (1962).

14) R. T. Simpson and B. L. Vallee, Biochemistry, 7, 4343 (1968).

15) D. C. Rees and W. N. Lipscomb, Proc. Natl. Acad. Sci. U.S.A., 78, 5455 (1981).

16) C.-M. Kam, N. Nishino and J. C. Powers, Biochemistry, 18, 3032 (1979). 
17) C.-I. Brändén, H. Eklund, B. Nordström, T. Boiwe, G. Söderlund, E. Zeppezauer, I. Ohlsson and $\AA$. Åkeson, Proc. Natl. Acad. Sci. U.S.A., 70, 2439 (1973).

18) C.-I. Brändén, H. Jörnvall, H. Eklund and B. Furugren, "The Enzymes," 3rd Ed., Vol. XI, ed. by P. D. Boyer, Academic Press Inc., New York, 1975, pp. $103 \sim 190$.

19) T. Boiwe and C.-I. Brändén, Eur. J. Biochem., 77, 173 (1977).

20) H. Weiner, I. Iweibo and P. L. Coleman, "Structure and Function of Oxidation-Reduction Enzymes," ed. by $\AA$. Åkeson and A. Ehrenberg, Pergamon Press Ltd., Oxford, 1972, pp. 619 627.

21) M. Frolich, D. J. Creighton and D. S. Sigman, Arch. Biochem. Biophys., 189, 471 (1978).

22) S. A. Evans and J. D. Shore, J. Biol. Chem., 255, 1509 (1980).

23) B. L. Vallee, F. L. Hoch, S. J. Adelstein and W. E. C. Wacker, J. Am. Chem. Soc., 78, 5879 (1956).

24) B. L. Vallee and W. E. C. Wacker, J. Am. Chem.
Soc., 78, 1771 (1956).

25) B. L. Vallee, S. J. Adelstein and J. A. Olson, J. Am. Chem. Soc., 77, 5196 (1955).

26) J. H. Harrison, Fed. Proc., 22, 493 (1963).

27) R. F. Colman and D. S. Foster, J. Biol. Chem., 245, 6190 (1970).

28) G. Pfleiderer, D. Jeckel, and T. Wieland, Biochem. Z., 330, 296 (1958).

29) G. Pfleiderer and E. H. Hohnholz, Biochem. Z., 331, 245 (1959).

30) A. Pesce, R. H. McKay, F. Stolzenbach, R. D. Cahn and N. O. Kaplan, J. Biol. Chem., 239, 1753 (1964).

31) M. G. Rossman, A. Liljas, C.-I. Brändén, and L. J. Manaszak, "The Enzymes," 3rd Ed., Vol. XI, ed. by P. D. Boyer, Academic Press Inc., New York, 1975, pp. $61 \sim 102$.

32) T. E. Barman, "Enzyme Handbook, "Vol. I, Springer-Verlag, Berlin, Heidelberg, 1969.

33) K. Kitagishi, K. Hiromi, K. Oda and S. Murao, J. Biochem., 93, 47 (1983). 